\title{
RESTORATION OF SPRUCE AND PINE IN NORTH-WEST RUSSIA
}

\author{
Natalia Belyaeva ${ }^{1}$, Dmitry Danilov ${ }^{2,1}$, Sergei Mandrykin ${ }^{1}$ \\ ${ }^{1}$ Saint-Petersburg State Forest Technical University named after S.M. Kirov, Russia \\ ${ }^{2}$ Leningrad Scientific Research Institute of Agriculture 'BELOGORKA', Russia \\ galbel06@mail.ru
}

\begin{abstract}
The analysis of regeneration processes on post-agrogenic lands allows establishing patterns and features of succession processes in phytocenosis, to identify the most appropriate measures to promote natural regeneration and to establish the possibility and feasibility of the production of forestry crops on lands left out of agricultural use. A study of forest regeneration processes in areas of fallow land for agricultural purposes adjacent to the floodplain of the Oredezh river in Gatchina district of Leningrad region. On the prepared study plots ( $0.25 \mathrm{ha})$ in different elements of the slope relief, the natural regeneration of pine and spruce and living ground cover was also taken into account. The soils on the objects of the study are agricultural soils of different thickness, from 30 to $45 \mathrm{~cm}$. In two areas the soil is turfy, well-cultivated, concealed podzolic, ferrous illuvial soil on sands. On plots No. 3-5, the soil is turfy, well-cultivated, concealed podzolic, ferrous illuvial, clayey, on a red loam. The purpose of the study was to identify the nature of forest regeneration processes in areas of fallow land for agricultural purposes. It has been established that the composition of the emerging undergrowth depends on a number of factors: the type of soil, the taxation characteristics of the adjacent forest, the forest vegetation subzone, and the living ground cover. In these soil conditions on the deposits, young mixed undergrowth with a predominance of spruce and pine after a meadow stage of ruderal vegetation is formed.

Key words: regeneration of spruce and pine, postagrogenic lands, sandy and loamy soils.
\end{abstract}

\section{Introduction}

Pine (Pinus sylvestris L.) and spruce (Picea abies $\mathrm{Kr}$.) belong to the main forest-forming species of the boreal zone. The analysis of regeneration processes on post-agrogenic lands allows establishing patterns and features of succession processes in phytocenosis, to identify the most appropriate measures to promote natural regeneration and to establish the possibility and feasibility of the forest crops production on lands left out of agricultural use. As of 2007, the total area of agricultural land used in Russia was estimated at 220 million ha. From 1961 to 2003, 58.3 million ha of land were withdrawn from economic circulation. From 1990 to 2007, the reduction of land used for arable land amounted to more than 10.8 million ha (Romanenko, 2008). A comparison of these values leads to the conclusion that during this period there was an increase in the deposit area by more than 20 million hectares. At present, about 56 million ha of agricultural land in Russia have been removed from circulation. In a number of regions of the North-West of Russia, about $40-60 \%$ of arable land is abandoned, and young softwoods grow there. Meanwhile, the lands excluded from the agricultural production have a high biological potential, as evidenced by the formation of highly productive undergrowth thereon (Kalinina et al., 2009; Lyury, Goryachkin, \& Karavaeva, 2010; Belousov, 2015; Golubeva, 2015; Danilov et al., 2016).

The data of different authors on the composition of undergrowth on the post-agrogenic lands vary greatly. On the southern border of the common pine area, pine stands of different thickness are formed on abandoned arable land
For the conditions of the Upper Volga region, it has been established that in the initial stages of settlement $10-12$ of tree-shrub species are involved in the deposits, of which only alder and birch belong to the predominant species in the formation of young growth. The formation of spruce forests without a change in the species composition in the territory of the European North may occur, including, on lands that used to be in agricultural use. Pine, alder, birch and willow take an active part in the regeneration of forest vegetation in fallow lands of the middle subzone of the taiga. Based on the analysis of literature data, the majority of naturally formed tree stands on former agricultural lands are distinguished by high productivity (Ia - I classes of bonitet).

The average bonitet of spruce plantations growing on farmlands is higher by 0.4 than that of spruce forests growing on indigenous lands. Lands left out of agricultural use have a leveled arable horizon, unlike forestlands, where the humus horizon is mosaic-related with the relief and parcel structure of vegetation, as well as the distribution of groups of trees. The acidity of these soils is also lower than the one of the forest soils, which makes mineral nutrients more accessible for tree species. The rate of overgrowing of plots depends on the area of abandoned fields. Plots up to 10 ha are overgrown in a few years after the withdrawal of land from agricultural use. On the plots of 100 ha or more, the process can be extended over decades. It is possible to speed up the process by implementing silvicultural activities aimed at promoting forest regeneration (Romanenko, 2008). Long-term use of land for arable land, although it leads to a profound transformation of ecosystems, does not preclude the 
possibility of their regeneration after the removal of anthropogenic load to a climax or subclimax state over the foreseeable period. Post-agrogenic successions on the deposits go towards the formation of zonal types of ecosystems according to classical succession schemes, which can be transformed by the initial states of the deposits during their withdrawal and their subsequent anthropogenic use (Kalinina et al., 2009; Romanenko, 2008). Post-agrogenic lands of the taiga zone of the North-West of the Russian Federation are at different stages of succession, which is manifested in the ecological and floristic features and the connection of certain plant species with the severity of microrelief. The lack of information and the disconnectedness of data on the course of the forest formation process on the former agricultural lands does not allow the formation of a scientifically based system of measures for the rational management of forestry in these areas. The solution of this problem requires a rational approach to the choice of the method of carrying out reforestation measures, ensuring the formation of high-yield forest stands of the required quality. This can be achieved through natural reforestation, with the use of effective measures to promote natural regeneration, as well as the creation of artificial tree plantations of various shapes and species. Based on the above, the purpose of the work carried out was the study of forest regeneration processes in areas of fallow lands.

\section{Materials and Methods}

The objects of study were areas of former arable land located in the most drained northern part of the Oredezhskoye plateau on Devonsky sandstones

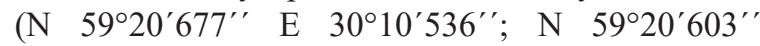
E $30^{\circ} 10^{\prime} 439^{\prime \prime}$; N $59^{\circ} 20^{\prime} 747^{\prime \prime}$ E $30^{\circ} 05^{\prime} 952^{\prime \prime} \mathrm{N}$ $59^{\circ} 20^{\prime} 739^{\prime \prime}$ E $\left.30^{\circ} 05^{\prime} 899^{\prime \prime}\right)$. Study areas of 0.25 hectares were laid in different elements of the slope relief of these areas and records were taken of the natural renewal of pine and spruce and of the living ground cover. Soil formation in this area takes place on a fairly young Quaternary relief, which was formed under the influence of several glacial processes, the result of which was a rather complex lithological pattern. At rather small areas thick deposits of sand moraine and loamy moraines are found, two-term deposits represented by sandy moraines, underlaid with loamy moraines and three-term deposits of sandy loam on moraine moraines, underlaid by Devonian sands, soil formation is also significantly affected by the difference in the depth underlain by loamy moraines. A strong microrelief has a strong effect. Soil cuts were made to determine the particle size distribution and thickness of the soil horizons. In all studied areas, the soil is agricultural ground $\left(\mathrm{A}_{\text {arable }}\right)$ of different thickness from 30 to $45 \mathrm{~cm}$. Due to the light grain size distribution and considerable cultivation, the podzolic horizon $\mathrm{A}_{2}$, and often the transition horizon $\mathrm{A}_{2} \mathrm{~B}$ in the profile, is not distinguished. Prescription deposits in the studied areas are of 25-35 years. The soil in plots No. $1-2$ is turfy well-cultivated concealed podzolic ferrous illuval soils on sands. In plots No. $3-5$, turfy is a well-cultivated concealed podzolic, ferrous illuval, clayey on a red-colored loam.

When considering the process of natural regeneration, the following indicators were defined, which allow assessing the success of forest regeneration: the number of undergrowth per unit area; reliability of undergrowth; the height structure of the undergrowth and the uniform distribution of the undergrowth by area (frequency).

Accounting of the undergrowth under the canopy of tree stands was carried out using two methods: continuous recounting and selective statistical method.

To take into account the number of undergrowth using circular sampling, circular platforms of $10 \mathrm{~m}^{2}$ or $\mathrm{R}=1.78 \mathrm{~m}$ were laid (Gryazkin, 1997).

Circular platforms were laid at the same distance from each other in a free move using at least 3 moves. The circular platforms were laid using a $178 \mathrm{~cm}$ long pole. The center of the next circular platforms was installed using the same pole, by moving it forward for two lengths.

In accordance with the generally accepted classifications (Rules for Reforestation, 2007), the undergrowth was divided:

1) by height - into 3 categories of coarseness: small - up to $0.5 \mathrm{~m}$, medium - 0.51-1.5 $\mathrm{m}$ and large more than $1.5 \mathrm{~m}$;

2) by density - into three categories: rare - up to 2 thousand, average density - 2-8 thousand, dense more than 8 thousand plants per 1 ha;

3 ) by distribution in area - into three categories depending on occurrence (occurrence of undergrowth is the ratio of the number of discount areas with plants to the total number of discount areas established in the study plot or the cutting area, expressed as a percentage): uniform - occurrence over $65 \%$; uneven occurrence of $40-65 \%$; group (at least 10 pieces of small or 5 pieces of medium and large copies of viable and close undergrowth).

The resulting material was processed using the methods of mathematical statistics according to the following formulas:

1) The number of undergrowth per hectare, pcs ha $^{-1}\left(\mathrm{M}_{\mathrm{ha}}\right)$ :

$$
\mathrm{M}_{\mathrm{ha}}=\frac{\sum N \cdot 10000}{n \cdot S},
$$

where $\Sigma \mathrm{N}$ is the total number of undergrowth on all discount areas, taking into account conversion factors, $\mathrm{n}$ is the number of discount areas, $\mathrm{S}$ is the area of onediscount areas $\left(10 \mathrm{~m}^{2}\right)$. 
Table 1

\section{Scope of survey}

\begin{tabular}{|c|c|c|c|}
\hline \multirow{2}{*}{ Study plot } & \multicolumn{2}{|c|}{ The number of measured stems of the undergrowth } & \multirow{2}{*}{$\begin{array}{c}\text { The number of discount areas for } \\
\text { accounting LGC }\end{array}$} \\
\cline { 2 - 4 } & To determine diameter & To determine height & 250 \\
\hline ПП1 & 984 & 1091 & 250 \\
\hline$\Pi \Pi 2$ & 1045 & 1050 & 83 \\
\hline$\Pi \Pi 3$ & 467 & 906 & 50 \\
\hline$\Pi \Pi 4$ & 355 & 709 & 61 \\
\hline$\Pi \Pi 5$ & 183 & 351 & \\
\hline
\end{tabular}

The total number of undergrowth, taking into account the recalculation of small and medium-sized undergrowth into large, specimens:

$$
\Sigma \mathrm{N}=0.5 \Sigma \mathrm{N}_{\mathrm{м}}+0.8 \Sigma \mathrm{N}_{\text {ср }}+\Sigma \mathrm{N}_{\text {кр }},
$$

where $\mathrm{N}_{\mathrm{u}}$ - the number of small undergrowth, specimens; $\mathrm{N}_{\mathrm{cp}}$ - the number of average undergrowth, specimens; $\mathrm{N}_{\text {кр }}^{\mathrm{cp}}$ - the number of large undergrowth, specimens.

Occurrence rate $\tau, \%$

$$
\tau=\frac{n_{1}}{n} \cdot 100
$$

where $n_{1}-$ is the number of discount areas where the undergrowth occurred.
2) The homogeneity coefficient - HC. This indicator shows the placement of undergrowth by area. If $\mathrm{HC}<1$, the distribution of undergrowth is random, if $\mathrm{HC} \approx 1$ the distribution is uniform, if $\mathrm{HC}>1$ this is the group distribution.

$$
\mathrm{HC}=\frac{\sigma^{2}}{\mathrm{M}_{\mathrm{sq}}} .
$$

\section{Results and Discussion}

The proximity of the semination source (at a distance of 40-50 $\mathrm{m}$ - wall of ripe mixed coniferous stand) allowed the pine tree and spruce to regenerate

\begin{tabular}{|c|c|c|c|c|c|c|c|}
\hline \multirow{3}{*}{$\begin{array}{l}\text { Study } \\
\text { plot }\end{array}$} & \multirow{3}{*}{$\begin{array}{l}\text { Undergrowth } \\
\text { composition }\end{array}$} & \multicolumn{6}{|c|}{ Characteristics of the undergrowth of the predominant breed } \\
\hline & & \multicolumn{3}{|c|}{ Average } & \multirow{2}{*}{$\begin{array}{l}\text { Number in } \\
\text { terms of large, } \\
\text { specimens ha }{ }^{-1}\end{array}$} & \multirow{2}{*}{$\begin{array}{c}\text { Occurrence, } \\
\tau, \%\end{array}$} & \multirow{2}{*}{$\begin{array}{c}\text { Homogeneity } \\
\text { coefficient } \\
\text { (HC) }\end{array}$} \\
\hline & & $\begin{array}{l}\text { Age } \mathrm{A}_{\text {mid }}, \\
\text { years }\end{array}$ & $\begin{array}{l}\text { Height } \mathrm{H}_{\text {mid }} \\
\mathrm{cm}\end{array}$ & $\begin{array}{c}\text { Accretion in height } \\
Z_{\text {mid }}, \mathrm{cm} \text { year }\end{array}$ & & & \\
\hline ПП 1 & $\begin{array}{c}6.4 \mathrm{P} \\
2.6 \mathrm{~S} \\
0.6 \mathrm{~A} \\
0.3 \mathrm{Al} \\
0.1 \mathrm{~B} \\
+\mathrm{WT} \\
\end{array}$ & 6.5 & 191.9 & 29.5 & 2.684 & 80.0 & 9.0 \\
\hline ПП 2 & $\begin{array}{c}7.2 \mathrm{P} \\
2.8 \mathrm{~S} \\
+\mathrm{B}+\mathrm{A} \\
\end{array}$ & 5.4 & 107.4 & 19.9 & 3.020 & 75.1 & 3.3 \\
\hline ПП 3 & $\begin{array}{c}5.2 \mathrm{~S} \\
2.6 \mathrm{WT} \\
2.0 \mathrm{~B} \\
0.1 \mathrm{Al} \\
0.1 \mathrm{O} \\
+\mathrm{A}\end{array}$ & 3.9 & 40.6 & 10.4 & 3.171 & 91.6 & 2.3 \\
\hline ПП 4 & $\begin{array}{c}5.0 \mathrm{~S} \\
1.6 \mathrm{~B} \\
3.2 \mathrm{WT} \\
0.2 \mathrm{O} \\
+\mathrm{P}\end{array}$ & 10.1 & 69.3 & 6.9 & 4.642 & 84.0 & 9.1 \\
\hline ПП 5 & $\begin{array}{c}5.1 \mathrm{~S} \\
0.1 \mathrm{P} \\
0.8 \mathrm{~B} \\
2.8 \mathrm{WT} \\
1.2 \mathrm{~A}\end{array}$ & 3.0 & 197.0 & 65.6 & 2.557 & 72.1 & 3.0 \\
\hline
\end{tabular}
successfully at plot No. 1 (Table 4.2). On the study plot

\section{Characteristics of the natural regeneration undergrowth on the objects of study}

Tree species: pine $-\mathrm{P}$, spruce $-\mathrm{S}$, aspen $-\mathrm{A}$, willow $-\mathrm{WT}$, birch $-\mathrm{B}$, alder $-\mathrm{Al}$, oak $-\mathrm{O}$. 
No. 1, the pine is prevailing species; the next in number is spruce. Birch, gray alder and aspen are represented to a much lesser extent. Single specimens represent tree willow. The average age of a pine tree was 7 years; the average height was $192 \mathrm{~cm}$. The density of pine undergrowth was 2.684 specimens ha $^{-1}$. Spruce undergrowth has an average age of 5 years, an average height of $74 \mathrm{~cm}$ and a density of 1.105 specimens ha ${ }^{-1}$ In the second plot, the regeneration of pine and spruce was also recorded (Table 2). On the trial plot No. 2, the dominant species is pine; spruce is represented to a lesser extent. Single birch and aspen are found. The average age of a pine tree was 5 years; the average height was $107 \mathrm{~cm}$. The density of pine undergrowth was 3020 specimens ha-1. Spruce undergrowth had an average age of 7 years, an average height of $90 \mathrm{~cm}$ and a density of 1.160 specimens $\mathrm{ha}^{-1}$. On the study plot No. 3, the predominant species is spruce. Birch and willow are represented slightly less. Aspen, alder and oak are represented in a small amount. On the study plot No. 4, the predominant species is spruce. Also, the willow tree is represented in a large number. Birch took a middle position in numbers on this trial plot. Single specimens represent pine and oak (Table). On the study plot No. 5, the predominant species is spruce. A slightly smaller number represents willow. Birch and aspen are represented almost equally, and the pine tree was encountered on the study plot least of all. Thus, on each study plot, undergrowth had an average density (from 2.557 specimens ha $^{-1}$ to 4.642 specimens $\mathrm{ha}^{-1}$ ). The largest number of undergrowth in the study plot No. 4 (4.642 specimens ha-1 probably was due to the weak development of the living ground cover $(53.3 \%)$. The smallest amount of undergrowth was found on the study plot No. 5 (2.557 specimens $\left.\mathrm{ha}^{-1}\right)$. This amount of undergrowth is due to the large projective cover of the living ground cover (103.2\%), which makes it difficult to develop undergrowth.

In all study plots the pine undergrowth is viable, insignificant amount of unviable undergrowth was observed in the study plots No. 1, 2, 5. Single dry undergrowth was observed on the study plot No. 2. On study plots No. 3 and No. 4, all undergrowth is viable. In general, the distribution of spruce undergrowth by categories of condition showed that the conditions for the development of viable undergrowth are optimal at this stage, which is associated with rare undergrowth and fertile growing conditions.

Pine undergrowth is generally viable. Dry undergrowth was not found on any of the study plots. On the study plot No. 1, all undergrowth was considered viable. The insignificant amount of unviable undergrowth was observed on the study area No. $2(2 \%)$. On study plots No. 4 and No. 5 unviable undergrowth was $20 \%$. This suggests favorable conditions for the emergence and development of pine undergrowth (Table 4).

When analyzing the height structure of the undergrowth, it is necessary to note its diversity and heterogeneity in the study plots. Summarizing the data, we can say that the share of large and mediumsized undergrowth at all sites was definitely more

Distribution of the spruce undergrowth by category status

Table 3

\begin{tabular}{|c|c|c|c|c|c|}
\hline \multirow[b]{2}{*}{ Study plot } & \multirow[b]{2}{*}{ Species } & \multicolumn{4}{|c|}{ Category of spruce undergrowth, $\%$} \\
\hline & & Viable & Non-viable & Dry & $\begin{array}{c}\text { Total } \\
\text { Without dry }\end{array}$ \\
\hline ПП 1 & \multirow{5}{*}{ Spruce } & 99.7 & 0.3 & 0 & 100 \\
\hline ПП 2 & & 98.3 & 1.7 & 0.01 & 100 \\
\hline ПП 3 & & 100 & 0 & 0 & 100 \\
\hline ПП 4 & & 100 & 0 & 0 & 100 \\
\hline ПП 5 & & 95.5 & 4.5 & 0 & 100 \\
\hline
\end{tabular}

Table 4

Distribution of the pine undergrowth by category status

\begin{tabular}{|c|c|c|c|c|c|}
\hline \multirow[b]{2}{*}{ Study plot } & \multirow[b]{2}{*}{ Species } & \multicolumn{4}{|c|}{ Category of pine undergrowth, $\%$} \\
\hline & & Viable & Non-viable & Dry & $\begin{array}{c}\text { Total } \\
\text { Without dry }\end{array}$ \\
\hline ПП 1 & \multirow{5}{*}{ Pine } & 100 & 0 & 0 & 100 \\
\hline ПП 2 & & 97 & 2 & 0 & 100 \\
\hline ПП 3 & & - & - & - & - \\
\hline ПП 4 & & 80 & 20 & 0 & 100 \\
\hline ПП 5 & & 80 & 20 & 0 & 100 \\
\hline
\end{tabular}


Table 5

Height structure of the natural regeneration undergrowth

\begin{tabular}{|c|c|c|c|c|}
\hline \multirow{2}{*}{ Species } & \multirow{2}{*}{ Study plot } & \multicolumn{3}{|c|}{ Height structure of the undergrowth, $\%$} \\
\hline & & small & medium & large \\
\hline \multirow[t]{5}{*}{ Spruce } & ПП 1 & 16 & 82 & 2 \\
\hline & ПП 2 & 12 & 84 & 4 \\
\hline & ПП 3 & 80 & 18 & 2 \\
\hline & ПП 4 & 51 & 41 & 8 \\
\hline & ПП 5 & 12 & 31 & 57 \\
\hline \multirow[t]{4}{*}{ Pine } & ПП 1 & 13 & 39 & 48 \\
\hline & ПП 2 & 15 & 66 & 19 \\
\hline & ПП 4 & 0 & 40 & 60 \\
\hline & ПП 5 & 20 & 0 & 80 \\
\hline
\end{tabular}

than the one of small undergrowth. In general, it can Such a high-rise structure suggests optimal conditions be said that the undergrowth was mostly medium, for the development of spruce undergrowth. Such and the average undergrowth prevailed in the study undergrowth is able to withstand under the influence plots No. 1 and No. 2. On study plots No. 3 and No. of adverse factors, such as high and low temperatures, 4 small undergrowth prevailed, and in No. 5 - large. and strong wind. Such undergrowth is competitive

Table 6

Dependence of the projective cover on the living ground cover and natural regeneration undergrowth of tree species

\begin{tabular}{|c|c|c|c|c|c|c|}
\hline \multirow{3}{*}{ Number } & \multicolumn{4}{|c|}{ Projective cover, $\%$} & \multirow{3}{*}{$\begin{array}{l}\text { Total projective } \\
\text { cover, } \%\end{array}$} & \multirow{3}{*}{$\begin{array}{c}\text { Number of tree species, } \\
\text { specimens } \text { ha }^{-1}\end{array}$} \\
\hline & \multicolumn{2}{|c|}{ grass } & \multirow{2}{*}{ shrubs } & \multirow{2}{*}{ mosses } & & \\
\hline & cereals, sedge & herbs & & & & \\
\hline ПП 1 & 9.6 & 75.0 & 0.04 & 3.86 & 88.5 & \begin{tabular}{|l} 
Pine 2684 \\
Spruce 1105 \\
Birch 58 \\
Aspen 121 \\
Willow 8 \\
Alder 100 \\
Total: 4076 \\
\end{tabular} \\
\hline ПП 2 & 24.22 & 57.18 & 0 & 1.9 & 83.3 & \begin{tabular}{|l|} 
Pine 3020 \\
Spruce 1160 \\
Birch 16 \\
Aspen 4 \\
Total: 4200 \\
\end{tabular} \\
\hline ПП 3 & 0.4 & 40.3 & 0 & 30.4 & 71.1 & \begin{tabular}{|l|} 
Spruce 3142 \\
Birch 2212 \\
Aspen 48 \\
Willow 2807 \\
Alder 133 \\
Oak 84 \\
Total: 8426 \\
\end{tabular} \\
\hline ПП 4 & 1.71 & 30.8 & 0 & 20.8 & 53.31 & $\begin{array}{l}\text { Pine } 92 \\
\text { Spruce } 4642 \\
\text { Birch } 2360 \\
\text { Oak } 260 \\
\text { Willow } 4460 \\
\text { Total: } 11814 \\
\end{array}$ \\
\hline ПП 5 & 36.3 & 50.66 & 0 & 6.0 & 92.96 & \begin{tabular}{|l} 
Pine 74 \\
Spruce 2557 \\
Birch 475 \\
Aspen 656 \\
Willow 1623 \\
Total: 5385
\end{tabular} \\
\hline
\end{tabular}


against other species and living ground cover for water and light. At the same time, the undergrowth of spruce is protected from the strong sunlight.

In the height structure of pine undergrowth, on the whole, large undergrowth prevails; there is not much undergrowth. Large undergrowth prevails on the study plots No. 1, 4, 5. On the study plot No. 2, the average height of undergrowth prevails. This height structure is formed based on the need for undergrowth of a pine tree to get enough light and water. Large undergrowth successfully survives in a competitive environment and is resistant to adverse climatic factors.

According to the number of undergrowth, spruce is characterized as average. Placement on the area is uniform. The value of the homogeneity coefficient indicates the group placement of the undergrowth $(\mathrm{HC}>1)$. This is due to the biological and environmental properties of spruce. In biogroups, coenotic connections between its components are preserved. Due to these connections, parcel isolation of spruce in groups is preserved. The resumption of hardwood in such biogroups is difficult, respectively; the chances spruce introductions into the main layer of the formed stand are many times higher. For single undergrowth spruce, with the exception of large specimens with a high growth rate, such chances are usually small. According to the number and density of undergrowth, pine is characterized as rare with group placement by area. The magnitude of the homogeneity coefficient is less than one $(\mathrm{HC}<1)$, which also indicates the random nature of the placement of undergrowth in the area. On these sample plots, the living ground cover prevents the emergence of pine undergrowth. Soil conditions are also affected, which are probably more suitable for the development of spruce undergrowth.

The data given below (Table 6) show that a number of regularities are revealed between the number of regrowth of tree species and the total projective cover of the living ground cover. There is a close connection between the number of undergrowth and the total projective cover of the living ground cover.
This is especially pronounced on the experimental object No. 4, where with a smaller total projective cover, the number of undergrowth is greater, and at the same time, there is no cereal and sedge plants. A great influence on the natural regeneration of tree species has a share of forbs, grass and sedge in the total projective cover. Between the undergrowth and the grass layer there is a competition for the light, the elements of mineral nutrition. Soil ramping also occurs. The increase in the share of cereal and sedge in the total projective cover entails a decrease in the number of undergrowth.

\section{Conclusions}

The composition of coniferous stands of spruce and pine depends on a number of factors:

1. The most important factors are soil type, characteristics of the adjacent forest and forest vegetation subzone.

2. At the surveyed plots, there is currently a successful renewal of economically valuable species - pine and spruce.

3. Density of coniferous undergrowth, its age and average height in these areas exceed the recommendations of the transfer to a wooded area of plantings of artificial or natural origin on the lands of the forest fund.

4. Soil has a significant impact on the development of undergrowth, largely determining the predominance of a particular tree species.

5. On sandy soils with underlying sand, the pine undergrowth prevails. Under loamy soils with underlaying loams, the undergrowth of spruce predominates. The presence of sod prevents the development of undergrowth. The cultivated soils are favorable for the undergrowth development.

6. In these soil conditions, on the deposits, a young mixed undergrowth is formed with a predominance of spruce and pine after a meadow stage of ruderal vegetation, depending on the underlying soil horizon under the former arable horizon.

\section{References}

1. Belousov, A.А. (2015). Культуры сосны обыкновенной (Pinus sylvestris L.) целевого назначения на вышедших из под сельскохозяйственного пользования землях в условиях среднего Заволжья (Cultures of Scots pine (Pinus sylvestris L.) purpose on the lands that came out of agricultural use in the conditions of the middle Trans-Volga region). Dissertation for the degree of Candidate of Agricultural Sciences Yoshkar-Ola (in Russian)

2. Danilov, D.A., Zhigunov, A.V., Krasnovidov, A.N., Ryabinin, B.N., Neverovsky, V.Yu., Shestakova, T.A., \& Anders, O.O. (2016). Выращивание древесных насаждений на постагрогенных землях (Growing of tree stands on post-agrogenic lands). Saint Petersburg: Publishing house of Polytechnic University, 130 p. (in Russian)

3. Gryazkin, A.V. (1997). Patent No. 2084129, Russian Federation, IPC C 6 A 01 G 23/00. Способ учета подроста (A method of accounting re-growth). No. 94022328/13; Declared 10.06.94; Published on July 20, 1997, Bulletin No. 20. (in Russian) 
4. Golubeva, L.V. (2015). Лесоводственно-экологическая трансформация постагрогенных земель на карбонатных отложениях в подзоне средней тайги Архангельской области (Forest-ecological transformation of post-agrogenic lands on carbonate sediments in the sub-zone of the middle taiga of the Arkhangelsk region). the dissertation of the candidate of agricultural sciences. Arkhangelsk: Northern (Arctic) Federal University named after MV Lomonosov, 160 p. (in Russian)

5. Kalinina, O., Goryachkin, S.V., Karavaeva, N.A., Lyuri, D.I., Najdenko, L., \& Giani, L. (2009). Selfrestoration of post-agrogenic sandy soils in the southern Taiga of Russia: Soil development, nutrient status, and carbon dynamics. Geoderma 152, 35-42.

6. Lyury, D.I., Goryachkin, S.V., \& Karavaeva, N.A. (2010). Динамика сельскохозяйственных земель России в XX веке и постагрогенное восстановление растительности и почв (The dynamics of agricultural lands in Russia in the $20^{\text {th }}$ century and the postagrogenic restoration of vegetation and soils). Moscow: GVOS, 416 p. (in Russian)

7. Romanenko, G.A. (2008). Агроэкологическое состояние и перспективы использования земель России, выбывших из активного сельскохозяйственного оборота (Agroecological state and prospects for the use of land withdrawn from active agricultural use). Moscow: Federal State 'Rosinformagroteh', 64 p. (in Russian)

8. Rules for Reforestation in Russian Federation (2007). 56 p. 